\title{
On the freshening of the northwestern Weddell Sea continental shelf
}

\author{
H. H. Hellmer ${ }^{1}$, O. Huhn ${ }^{2}$, D. Gomis ${ }^{3}$, and R. Timmermann ${ }^{1}$ \\ ${ }^{1}$ Alfred Wegener Institut für Polar und Meeresforschung, Bremerhaven, Germany \\ ${ }^{2}$ Institut für Umweltphysik, Universität Bremen, Bremen, Germany \\ ${ }^{3}$ IMEDEA, Universitat de les Illes Balears - CSIC, Mallorca, Spain
}

Received: 3 November 2010 - Published in Ocean Sci. Discuss.: 8 December 2010

Revised: 7 April 2011 - Accepted: 20 April 2011 - Published: 6 May 2011

\begin{abstract}
We analyzed hydrographic data from the northwestern Weddell Sea continental shelf of the three austral winters 1989, 1997, and 2006 and two summers following the last winter cruise. During summer a thermal front exists at $\sim 64^{\circ} \mathrm{S}$ separating cold southern waters from warm northern waters that have similar characteristics as the deep waters of the central basin of the Bransfield Strait. In winter, the whole continental shelf exhibits southern characteristics with high Neon $(\mathrm{Ne})$ concentrations, indicating a significant input of glacial melt water. The comparison of the winter data from the shallow shelf off the tip of the Antarctic Peninsula, spanning a period of $17 \mathrm{yr}$, shows a salinity decrease of 0.09 for the whole water column, which has a residence time of $<1 \mathrm{yr}$. We interpret this freshening as being caused by a combination of reduced salt input due to a southward sea ice retreat and higher precipitation during the late 20th century on the western Weddell Sea continental shelf. However, less salinification might also result from a delicate interplay between enhanced salt input due to sea ice formation in coastal areas formerly occupied by Larsen A and B ice shelves and increased Larsen C ice loss.
\end{abstract}

\section{Introduction}

Climate change in the Southern Hemisphere is strongly evidenced by the atmospheric temperature rise of nearly $3{ }^{\circ} \mathrm{C}$ since 1951 at the Antarctic Peninsula (King, 1994). The decay of Wilkins Ice Shelf $\left(70^{\circ} 15^{\prime} \mathrm{S}, 73^{\circ} 0^{\prime} \mathrm{W}\right)$ at the western periphery (Braun and Humpert, 2009) is supposed to be the most recent consequence of the warming. For this region, Meredith and King (2005) report a warming of $1^{\circ} \mathrm{C}$ and a salinification of the surface waters for the summers 1955-

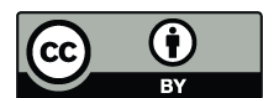

Correspondence to: $\mathrm{H}$. H. Hellmer (hartmut.hellmer@awi.de)
1998. The warming and salinification are caused by reduced sea ice formation and thus decreased fresh water input due to melting. A similar long-term change in shelf water salinity, however of opposite sign, has been reported from the Ross Sea continental shelf (Jacobs and Giulivi, 2010) with consequences for the characteristics of Antarctic Bottom Water in the Indian Ocean (Rintoul, 2007). The continuous freshening since the early 1960s might have been caused remotely by increased freshwater input due to ice shelf basal melting in Amundsen and Bellingshausen Seas (Rignot and Jacobs, 2002). Other measurements from the Antarctic continetal shelf covering several decades are rare and mostly summer biased.

Such limitation holds for the western Weddell Sea. Recent observations show that this area hosts significant but intermittend sources for deep and bottom water (Schröder et al., 2002; Absy et al., 2008). The formation of deep water masses strongly depends on the availability of dense shelf water with salinities above 34.465 at a $500-\mathrm{m}$ deep continental shelf break - the threshold increases for shallower shelves (Gill, 1973). The decay of Larsen A and B ice shelves (Rack and Rott, 2004) could have influenced the water salinity on the northwestern Weddell Sea continental shelf in two ways, due to: (1) iceberg grounding and consecutive melting and (2) sea ice formation and salinification of the water column in coastal polynyas formerly covered by the ice shelves (C. Haas, personal communication, 2010). Satellite images show that the Larsen A and B icebergs drifted fast away from the continental shelf or grounded at the rim of the shallow shelf off the tip of the Antarctic Peninsula (C. Wesche, personal communication, 2010). The coastal polynyas, in return, are located over relative deep basins (Gilbert et al., 2003) thus retaining salty (= dense) shelf water. The polynya processes might influence the wider shelf water density once the basins are filled, but a compensating influence of both processes can be excluded. 
Table 1. Cruise details, separated in the cruises analysed (upper five) and used as supplement (lower six). For simplicity, the official cruise name was converted to a more suitable (season_year) nomenclature. AS = austral summer, AF = austral fall, AW = austral winter. WWGS = Winter Weddell Gyre Study (Augstein et al., 1991), DOVETAIL = Deep Ocean VEntilation Through Antarctic Intermediate Layers (Muench and Hellmer, 2002), ISPOL = Ice Station POLarstern (Hellmer et al., 2008), WWOS = Winter Weddell Outflow study (Lemke, 2009), ATOS2 was the Antarctic part of the bipolar Spanish project ATOS, standing for "Intake of Atmospheric Organic Carbon and Pollutants by the Polar Oceans".

\begin{tabular}{lllll}
\hline Cruise Lable & Ship & Period & Cruise Name & Acronym \\
\hline AW_89 & R/V Polarstern & 6 September 1989-31 October 1989 & ANT-VIII/2 & WWGS \\
AW_97 & R/V Nathanial B. Palmer & 31 July 1997-8 September 1997 & NBP9705 & US-DOVETAIL \\
AW_06 & R/V Polarstern & 24 August 2006-20 October 2006 & ANT-XXIII/7 & WWOS \\
AS_06 & R/V Polarstern & 23 November 2006-30 January 2007 & ANT-XXIII/8 & N/A \\
AS_09 & R/V Hesperides & 24 January 2009-2 March 2009 & ATOS2 & ATOS \\
AS_90 & R/V Polarstern & 17 November 1990-31 December 1990 & ANT-IX/2 & N/A \\
AS_92 & R/V Polarstern & 3 December 1992-22 January 1993 & ANT-X/7 & N/A \\
AF_96 & R/V Polarstern & 17 March 1996-19 May 1996 & ANT-XIII/4 & N/A \\
AF_98 & R/V Polarstern & 28 March 1998-21 May 1998 & ANT-XV/4 & DOVETAIL \\
AS_04 & R/V Polarstern & 6 November 2004-19 January 2005 & ANT-XXII/2 & ISPOL \\
AS_08 & R/V Polarstern & 6 February 2008-16 April 2008 & ANT-XXIV/3 & GEOTRACES \\
\hline
\end{tabular}

During the Winter Weddell Sea Outflow Study (WWOS; see Table 1 for details of all cruises used in this study) to the northwestern Weddell Sea (Lemke, 2009) hydrographic stations covered the continental shelf at the Antarctic Peninsula north of $65.1^{\circ} \mathrm{S}$, revisiting a few stations of a 1989 austral winter cruise (WWGS; Table 1) just northeast of the peninsula (Fig. 1). Heavy sea ice and a huge amount of grounded icebergs prevented easy manoveuring and an exact reoccupation. However, the homogenous shelf water column in winter allows for a comparison over small horizontal distances and, therefore, the additional consideration of hydrographic data from the US-DOVETAIL cruise NBP9705 (Fig. 1b). In the following, we describe the hydrographic conditions on the northwestern Weddell Sea continental shelf for the austral winter of 2006. Estimates of the freshwater input due to melting of deep-drafted meteoric ice and the transit times, i.e. the time elapsed since the water has left the surface mixed layer, are based on neon (Ne) and chlorofluorocarbon (CFC) distributions, respectively. The consideration of the two winter cruises in 1989 (AW_89) and 1997 (AW_97) allows for a comparison of winter conditions over a $17-y r$ period. In addition, hydrographic data from two consecutive austral summers 2006/07 (AS_06; Gutt, 2008) and 2009 (AS_09) is decribed to investigate the seasonal transition of the whole shelf water column in view of the long-term changes observed on the continental shelf.

\section{Data and methods}

For the hydrographic measurements during AW_06 and AS_06 a Seabird 911+ CTD (conductivity-temperaturedepth) connected to a carousel (SBE 32) with 24 12-1 water bottles was used. The instrument system consisted of two sensor pairs of temperature (SBE-03) and conductivity (SBE-04), a high precision pressure sensor Digiquartz, one oxygen sensor (SBE-43), a Benthos altimeter, and a Wetlabs C-Star transmissiometer. Conductivity and temperature sensor calibration was performed prior to and after the cruise at Seabird Electronics. The accuracy of the temperature sensors can be given to $2 \mathrm{mK}$. The readings for the pressure sensors are better than $2 \mathrm{dbar}$. The conductivity was corrected based on salinity measurements from water samples using a Guildline Autosal 8400 with the IAPSO Standard Seawater from the P-series P145. According to the water sample correction, salinity was measured to an accuracy of 0.002 .

ATOS2 also operated with a Seabird 911 CTD-probe, equipped with oxygen and fluorescence sensors. Water samples were obtained at different depths at every station in order to measure salinity, dissolved oxygen and other biochemical parameters. Regarding salinity, a total of 90 samples were analyzed onboard with a Guildline Portasal 8410A, calibrated with IAPSO Standard Seawater ampoules. The salinity of the samples ranged from 34.35 to 34.72 . The linear regression between water samples and CTD values resulted in a correlation coefficient of 0.997 . The mean value for the salinity residuals after the linear regression was 0.003 .

During AW_06 a total of 46 stations were sampled in four main areas (Fig. 2):

- South Scotia Ridge with the passages to the east (South Orkney $-41^{\circ} \mathrm{W}, 61^{\circ} \mathrm{S}$ ) and to the west (Philip $-49^{\circ} \mathrm{W}$, $61^{\circ} \mathrm{S}$ ) of the South Orkney Plateau.

- Powell Basin.

- Eastern Bransfield Strait Basin.

- Northwestern Weddell Sea continental shelf and slope. 

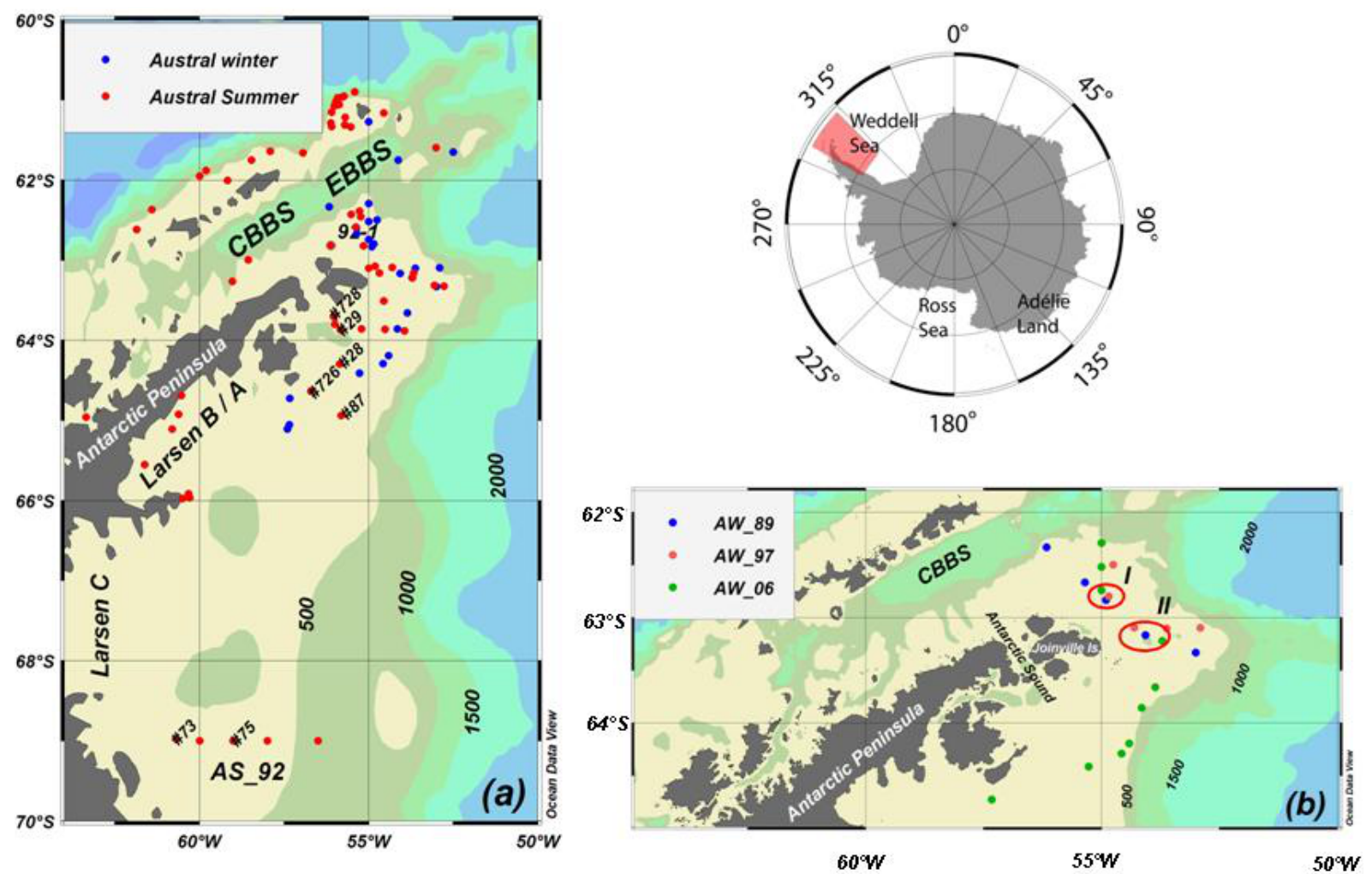

Fig. 1. Maps zoomed into the northwestern Weddell Sea (see inset) for (a) station distribution of austral winter (blue) cruises AW_89, AW_97, and AW_06, the Winter Weddell Sea Outflow Study (WWOS), together with austral summer (red) cruises AS_92, AS_06, and AS_09 (ATOS2) to the shallow $(<500 \mathrm{~m}$ ) western Weddell Sea continental shelf (see Table 1 for cruise details). Numbers refer to stations used in Fig. 6 (AS_09-28, AS_09-29, AS_09-87, AS_06-726, AS_06-728), Fig. 8 (AS_92-75), and in the text (AS_92-73). Additional zoom for (b) shallow-shelf station distribution of the three winter cruises - see insert for color/cruise relation. Ellipse (I and II) encircles the stations providing the data for the $\theta / \mathrm{S}$ diagrams (Fig. 3) and the profiles (Fig. 8). Depth contours are labeled and color-coded identically. $\mathrm{CBBS}=$ Central Basin of the Bransfield Strait, EBBS $=$ Eastern Basin of the Bransfield Strait.

Although a high or equally spaced distribution was desired, the actual position of the stations was strongly influenced by local bathymetry, which often had to be determined first by means of multi-beam surveys, and winter sea ice conditions. As a consequence only ten casts were conducted in the shallow waters (down to 440-m depth; Fig. 1b) off the northern coast of the Antarctic Peninsula supplemented by four stations on the continental slope at $\sim 64.2^{\circ} \mathrm{S}$ down to 2500-m depth (blue square plus one in Fig. 2).

Full depth sampling for stable noble-gas isotopes and CFCs occurred at a subsample of the AW_06 CTD-stations (Fig. 2). Water samples for noble-gases were tapped from the niskin bottles into copper tubes, carefully preventing contamination with air during the filling. The samples were later analyzed in the Institut für Umweltphysik (IUP) Bremen noble gas mass spectrometry lab (Sültenfuß et al., 2009). The measurements achieve a precision of $\pm 0.8 \%$ or better for helium and neon concentrations and $\pm 0.4 \%$ for $\delta^{3} \mathrm{He}\left(\delta^{3} \mathrm{He}=100\right.$ $\left.\left(\left[{ }^{3} \mathrm{He} /{ }^{4} \mathrm{He}\right]_{\text {obs }} /\left[{ }^{3} \mathrm{He} /{ }^{4} \mathrm{He}\right]_{\mathrm{atm}}-1\right)[\%]\right)$. Water samples for CFC analysis were collected from the CTD/rosette system into 100-ml glass ampoules and sealed off after a CFC free headspace of pure nitrogen had been applied. The CFC samples were later analysed in the CFC-laboratory at the IUP Bremen (Bulsiewicz et al., 1998). The accuracy of the measurement is better than $1.5 \%$ for both CFC-11 and CFC-12, which corresponds to $0.04 \mathrm{pmol} \mathrm{kg}^{-1}$ and $0.03 \mathrm{pmol} \mathrm{kg}^{-1}$, respectively. CFC concentrations are calibrated on the SIO98 scale (Prinn et al., 2000).

For spatial and temporal comparison we also use noblegas and CFC data from Ice Station Polarstern (AS_04) on the slope off the Larsen C Ice Shelf (Huhn et al., 2008) as well as from AS_90, AF_96, AF_98, and from AS_08 in the northwestern Weddell Sea (O. Huhn, unpublished data).

\section{Observations}

The northwestern Weddell Sea shelf water column $(<500 \mathrm{~m}$ deep) in austral winters is characterized by a narrow range in potential temperature/salinity $(\theta / \mathrm{S})$-space (gray dots in Fig. 3) with the fresh (and warm) summer surface layer missing. The highest temperatures $\left(>-1.1^{\circ} \mathrm{C}\right)$ are found at 


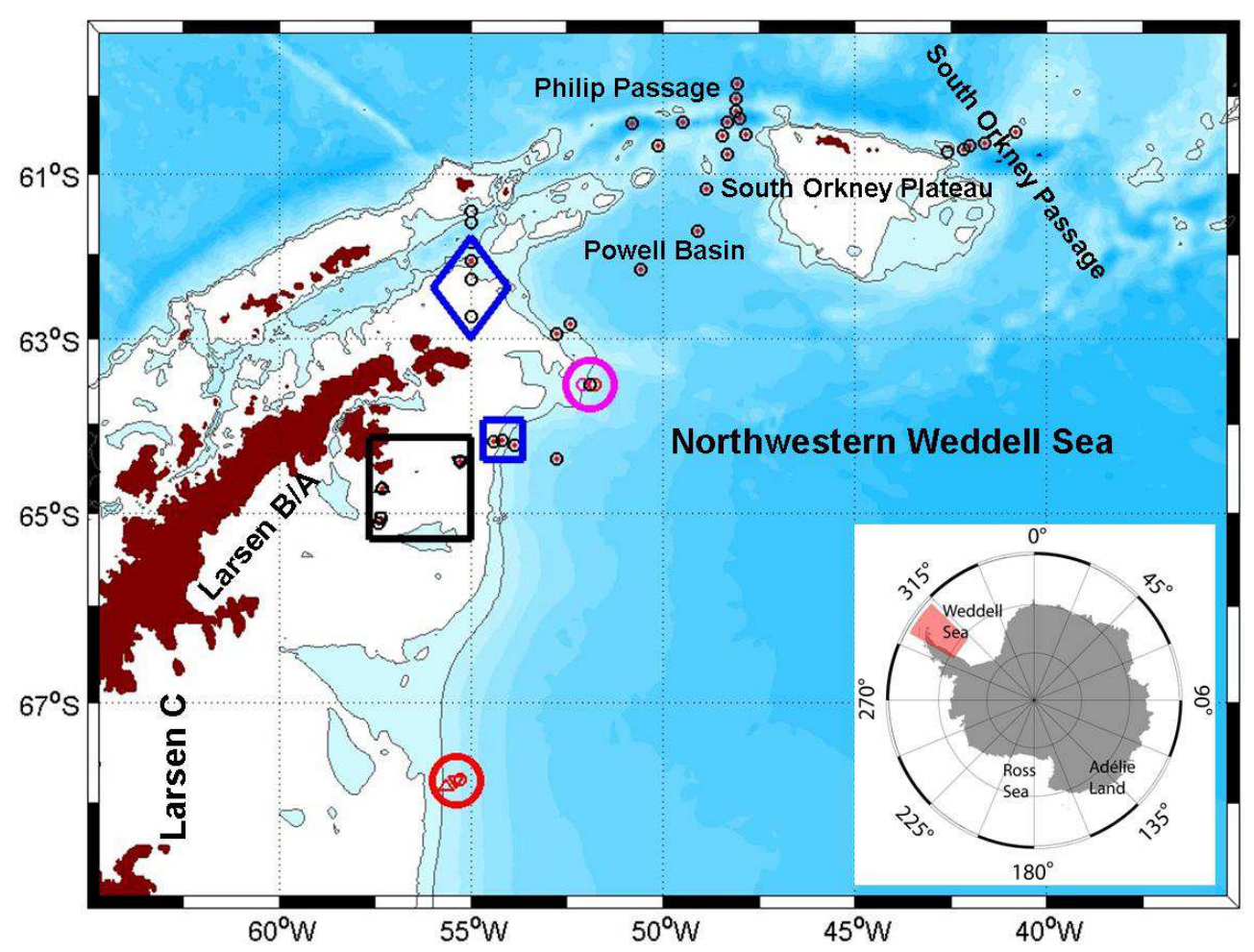

Fig. 2. Station distribution of austral winter cruise AW_06 to the northwestern Weddell Sea differentiated by profiles with noble gas measurements (red dots) and CFC measurements (black open circles). The black square (with triangles, square, and circle) encloses stations which provide the neon values (Fig. 4), GMW fractions (Fig. 5), and CFC-12 values (Fig. 7). The blue diamond (blue square) borders stations which provide the CFC-12 profiles, displayed as "x" ("+") in Fig. 7. The magenta circle surrounds stations from previous summer cruises for which the neon profiles are displayed in Fig 10. In addition, the red circle (including triangles and circle) encloses AS_04 (ISPOL) stations which provide the neon values added to Fig. 4. The thin grey lines represent the 500-m and 1000-m isobaths.
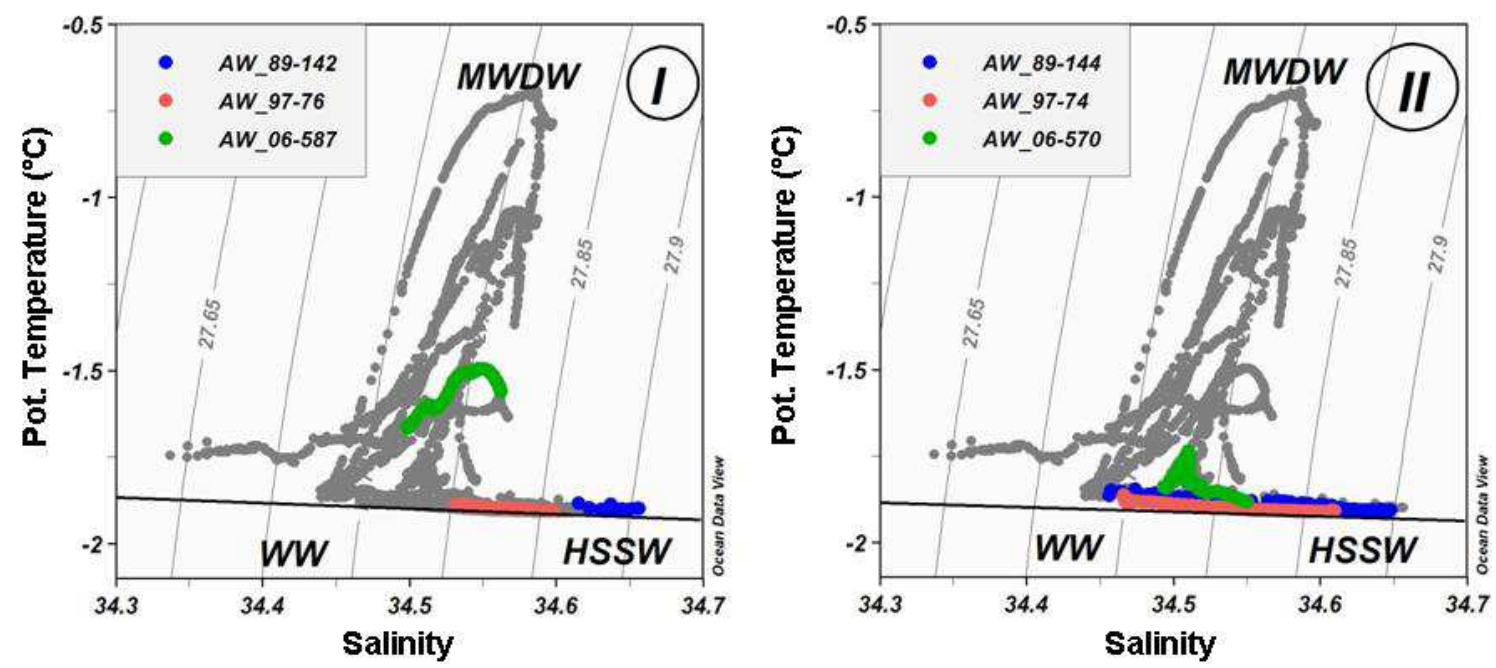

Fig. 3. Austral winter $\theta / \mathrm{S}-$ characteristics on the shallow $(<500 \mathrm{~m})$ northwestern Weddell Sea continental shelf for cruises AW_89, AW_97, and AW_06, in gray, together with selected stations from the areas I and II (Fig. 1b), sampled during austral winters of 1989 (blue), 1997 (red), and 2006 (green). The lower line represents the surface freezing temperature as a function of salinity. Isopycnals are drawn relative to surface pressure $\left(\sigma_{0}\right)$. MWDW $=$ Modified Warm Deep Water, WW = Winter Water, HSSW = High Salinity Shelf Water. 


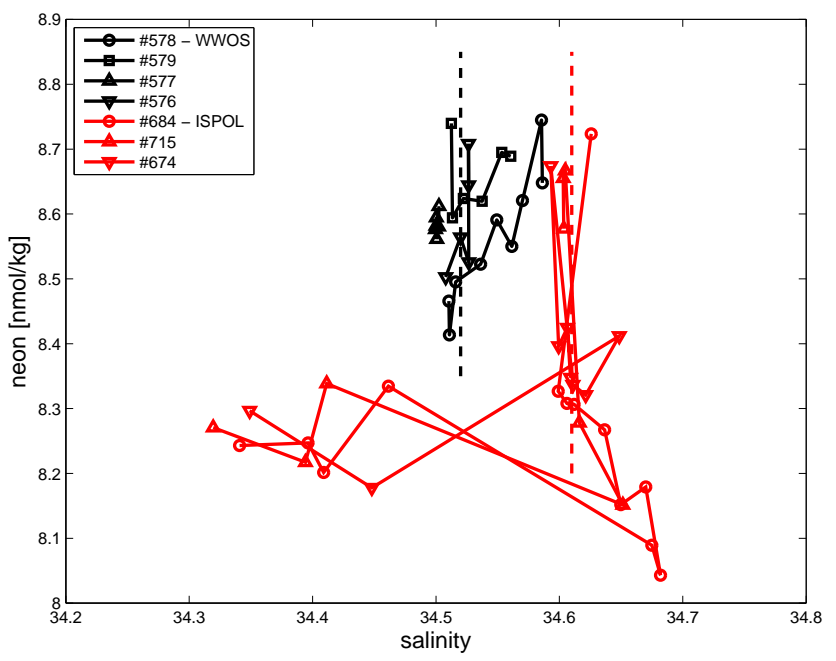

Fig. 4. Neon concentrations $\left[\mathrm{nmol} \mathrm{kg}^{-1}\right]$ vs. salinity from the four southernmost AW_06 (WWOS) stations (black square in Fig. 2) and selected AS_04 (ISPOL) stations (red circle in Fig. 2). The typical error of the Ne measurements is in the order of $0.07 \mathrm{nmol} \mathrm{kg}^{-1}$. The dashed vertical lines in black and red represent the mean salinity values for the bottom layer (lowest $50 \mathrm{~m}$ ).

stations close to the continental shelf break (Fig. 1b). Maximum temperature together with the characteristic (hook) shape in $\theta / \mathrm{S}$-space identifies Modified Warm Deep Water (MWDW) originating from the Warm Deep Water (WDW) of the Weddell Sea or eastern basin of the Bransfield Strait (Gordon et al., 2000). The cluster at lower temperature, clearly separated from the stations with strong MWDW influence, represents inner shelf stations. Here, traces of MWDW are sandwiched between Winter Water (WW), at the surface freezing point, and saltier waters, termed High Salinity Shelf Water (HSSW). These stations are also characterized by high ${ }^{4} \mathrm{He}$ (not shown) and Ne values (Fig. 4) solely caused by the presence of glacial melt water. In the western Weddell Sea the same high ${ }^{4} \mathrm{He}$ and $\mathrm{Ne}$ values were found so far only on the continental slope off Larsen C Ice Shelf during the ISPOL experiment (Huhn et al., 2008).

To determine the fraction and inventory of pure glacial melt water, we used the Optimum Multiparameter Analysis (OMP; Tomzcak, 1981; Tomczak and Large, 1989) identical to the approach in Huhn et al. (2008). As source water types we considered pure glacial melt water (GMW, with characteristic ${ }^{4} \mathrm{He}$ and Ne excess, Hohmann et al., 2002), Winter Water, High Salinity Shelf Water, and Warm Deep Water. To quantify the contribution of each source water type we used the following parameters as constraints: potential temperature, salinity, ${ }^{4} \mathrm{He}, \mathrm{Ne}, \delta^{3} \mathrm{He}$, and mass conservation. The source water type properties and their variance used for the OMP are listed in Table 2. In OMP, the parameters $p$ (e.g., potential temperature) were first normalized (so that all parameters measured in different units are compara- ble) to $p_{i}^{\prime}=p_{i}-$ mean $\left(p_{i}\right) / \sigma\left(p_{i}\right)$, were $\sigma\left(p_{i}\right)$ is the standard deviation for each parameter and weighted (to account for the different measurement accuracies of each parameter) by $\sigma\left(p_{i}\right) / \delta$, where the $\delta$ is the largest of water mass variances. It turns out that ${ }^{4} \mathrm{He}$ and $\mathrm{Ne}$ are the most sensitive parameters for determining glacial melt water fractions (varying $\delta_{\mathrm{He}}$ and $\delta_{\mathrm{Ne}}$ by a factor of 2 , melt water fractions deviate by $14 \%$, whereas varying $\delta_{\text {temp }}, \delta_{\text {sal }}$ or $\delta_{\delta^{3} \mathrm{He}}$ in the same order, glacial melt water fractions deviate by less than $2 \%$. With $\delta=1$ for the mass conservation constraint the residuals are forced to be negligible. For the four available stations in the southern WWOS area (all on the continental shelf shallower than $500 \mathrm{~m}$ ) we determined GMW fractions up to $0.4 \%$ (Fig. 5), comparable to those at the ISPOL sites. The fractions for WDW are between zero and $10 \%$, and for HSSW and WW between $20 \%$ and $70 \%$, whereas HSSW and WW have almost reverse profiles and add to $90 \%$ in the mean.

The $\theta / \mathrm{S}$-space of the consecutive austral summer of 2006/07 shows a pronounced difference in shelf water temperatures across $64^{\circ} \mathrm{S}$, with a maximum difference of $0.75^{\circ} \mathrm{C}$ in the bottom layer (Fig. 6). The "thermal" difference reduces to $0.5^{\circ} \mathrm{C}$ with a more southern transition $\left(\sim 64.5^{\circ} \mathrm{S}\right)$ for the denser sampled austral summer of 2009. This difference might have been the same in 2006/07, since the $\theta / \mathrm{S}$ curve of Station AS_06-728 (yellow) follows that of Station AS_09-28 (orange) towards low temperatures and high salinities but in shallower waters, $283 \mathrm{~m}$ vs. $397 \mathrm{~m}$. It demonstrates the potential of a variable (but largely unknown) shelf topography to accumulate cold and salty (= dense) shelf waters. The near-bottom $\theta / \mathrm{S}$ tendency at Station AS_09-29 (red) towards warm and salty water also exists for stations further to the east (Fig. 1a), indicating that in summer traces of MWDW extend as far as the southern entrance of the Antarctic Sound at $\sim 56^{\circ} \mathrm{W}$. The higher bottom salinities for stations south of $\sim 64^{\circ} \mathrm{S}$ (Fig. 6) indicate the remnants of salt enrichment due to winter sea ice formation. Temperatures below the surface freezing point indicate Ice Shelf Water (ISW). In austral summer 2006/07 the southernmost stations were occupied at $\sim 66^{\circ} \mathrm{S}$, near the northern front of Larsen C ice shelf (Fig. 1a) where Nicholls et al. (2004) already had observed the outflow of glacial melt water.

\section{Discussion}

\subsection{Summer conditions}

Summer conditions on the northwestern Weddell Sea continental shelf (Fig. 6) are characterized by shelf waters covering a broader (than in winter) density range with warm/fresh surface waters on top of cold/salty winter remnants. A MWDW signature, if present, only exists close to the bottom (e.g., AS_09-29). Compared to the previous winter (green curve in Fig. 3) the bottom layer remains at nearly the same salinity but shifts towards higher temperature. Such seasonal 
Table 2. Source water properties used for the Optimum Multiparameter Analysis (OMP). GMW = Glacial Melt Water, WW $=$ Winter Water, $\mathrm{HSSW}=$ High Salinity Shelf Water, WDW $=$ Warm Deep Water. The $\delta$ is used to determine the weight $w=\sigma\left(p_{i}\right)^{2} / \delta$.

\begin{tabular}{llllll}
\hline Properties & GMW & WW & HSSW & WDW & $\delta$ \\
\hline Pot. temperature $\left[{ }^{\circ} \mathrm{C}\right]$ & -2.3 & -1.844 & -1.928 & 0.351 & 0.10 \\
Salinity & 0.00 & 34.378 & 34.817 & 34.667 & 0.03 \\
${ }^{4} \mathrm{He}[\mathrm{nmol} \mathrm{kg}-1$ & 25.70 & 1.856 & 1.920 & 1.880 & 0.02 \\
$\mathrm{Ne}\left[\mathrm{nmol} \mathrm{kg}{ }^{-1}\right]$ & 89.20 & 8.217 & 8.467 & 8.134 & 0.07 \\
$\delta^{3} \mathrm{He}[\%]$ & -1.80 & -0.114 & -0.806 & 7.148 & 0.4 \\
Mass conservation $\sum X_{i}$ & 1 & 1 & 1 & 1 & 1 \\
\hline
\end{tabular}

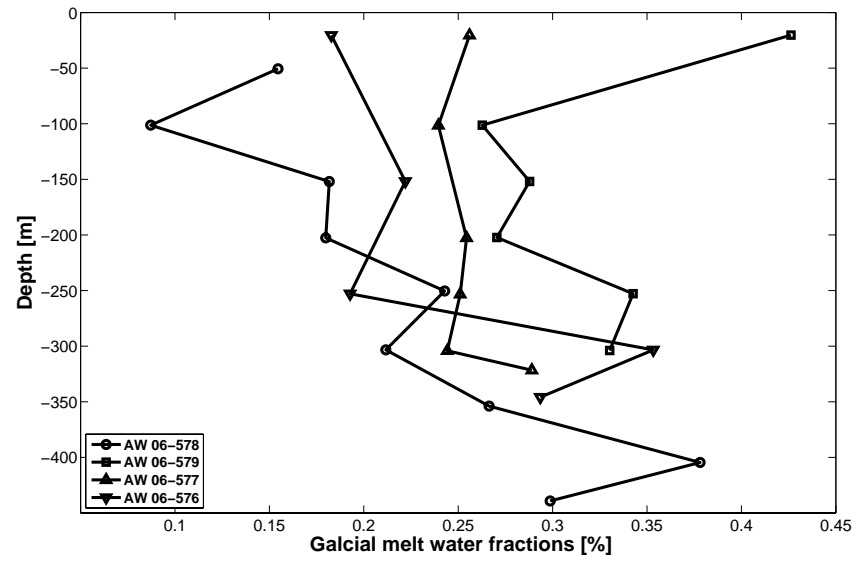

Fig. 5. Depth profiles of glacial melt water fraction [\%] for the four southernmost AW_06 (WWOS) stations on the western Weddell Sea continental shelf (black square in Fig. 2). The GMW fraction mean is $0.25 \%$ with a standard deviation of $0.07 \%$. The surface sample at station AW_06-579 might be an outlier, because $\mathrm{He}$ and $\mathrm{Ne}$ samples both are comparably too high for surface water, which indicates contamination by air. To compensate for the high values, OMP would overestimate the GMW value.

fluctuations near the bottom were also observed at a mooring site northeast of Joinville Island, recording from May 1996 to March 1998 in 280-m deep waters (von Gyldenfeldt et al., 2002). The missing cold "salty foot" at the warmer northern stations indicates the drainage of dense shelf waters into the fringing Weddell Sea and Bransfield Strait basins at the end of winter. It is noteworthy that for the Weddell Sea a continental slope mooring (AWI_207) from the same experiment as above (von Gyldenfeldt et al., 2002) shows a temperature decrease during summer as well as a year-by-year (19961998) salt reduction of 0.013 and 0.02 (Fig. 11 in Schröder et al., 2002). For the central basin of the Bransfield Strait the strongest freshening of waters deeper than $1000 \mathrm{~m}$ and colder than $-1.4{ }^{\circ} \mathrm{C}$ of $\sim 0.05$ occurred for the period 1990 to 2005 (Garcia and Mata, 2005). Although in good agreement with our observations, the less freshening might be caused by mixing with saltier deep water as the cold shelf water descends from the continental shelf. The deep temperature does not

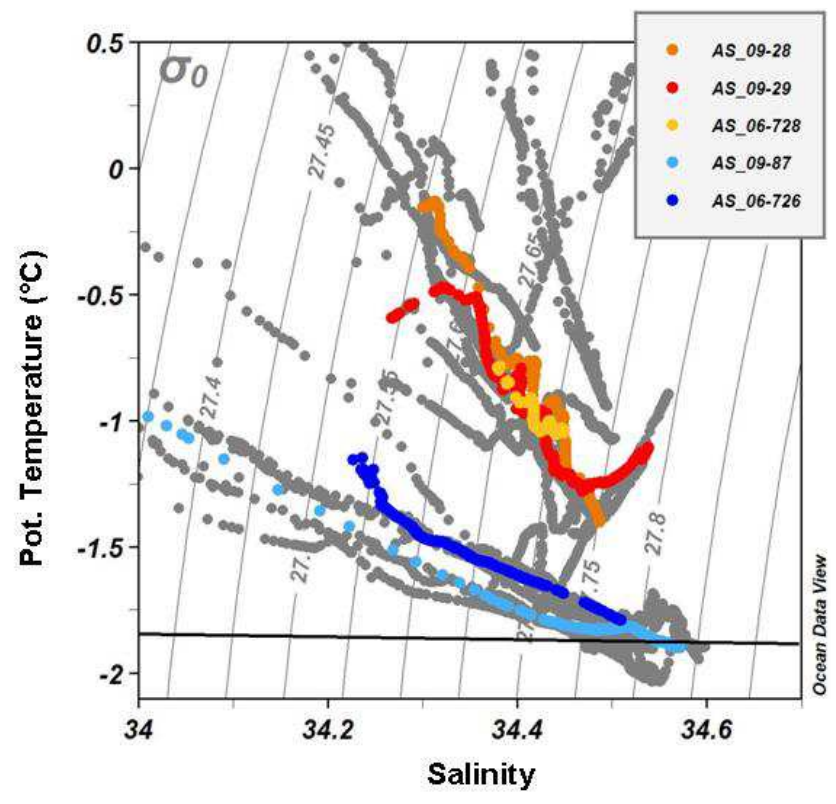

Fig. 6. Austral summer $\theta / \mathrm{S}$-characteristics (gray) on the shallow $(<500 \mathrm{~m})$ northwestern Weddell Sea continental shelf for cruises AS_06 and AS_09 (red dots in Fig. 1a). Colored dots depict certain stations (see insert) representing the two different "thermal" regimes on the continental shelf. The lower line represents the surface freezing temperature as a function of salinity. Isopycnals are drawn relative to surface pressure $\left(\sigma_{0}\right)$.

show a trend, and a seasonal cycle was not recorded since the data is based on hydrographic summer surveys only.

The warming of the WW in relatively shallow waters could be caused by downward mixing of surface waters resulting from enhanced storm activity during spring together with a retreating sea ice cover or from tidal action on the continental shelf (Robertson et al., 1998). Indeed, for the northwestern Weddell Sea the long-term mean of sea level pressure shows the highest meridional gradient in February (NOAA, 2009). The pattern is comparable with that of the winter months, but starting in July the low-pressure centers are located more to the South. The rapid mixing of surface water to greater depth is also evident from CFC measurements 


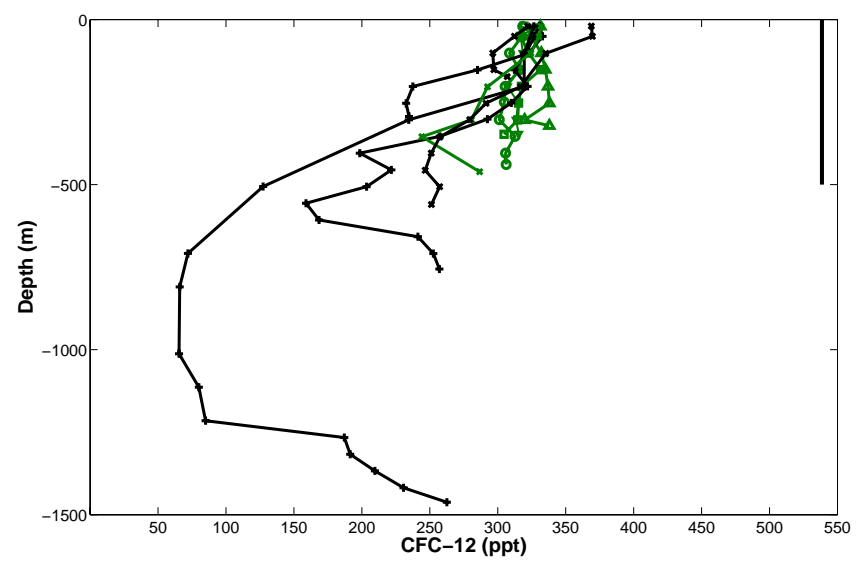

Fig. 7. CFC-12 [ppt] profiles from the northwestern Weddell Sea continental shelf $(<500 \mathrm{~m}$; green profiles from black square in Fig. 2) and the continental slope (black profiles; " $x$ " from northern stations - blue diamond in Fig. 2; "+" from western stations blue square in Fig. 2) sampled during AW_06. The green symbols (circles, squares, and triangles) correspond to those in the noble gas vs. salinity diagram (Fig. 4). The solid line at 539 ppt depicts the atmospheric (equilibrium) partial preassure relative to the year 2006.

during AW_06, showing nearly the same values over the whole shelf water column (green circles, squares, and triangles in Fig. 7), while confined to the surface layer over the deep basin (+ in Fig. 7). All CFC surface values have a relatively low saturation in the order of $60 \pm 2 \%$ due to a dense sea ice cover. Towards the north, surface water saturation is higher because of a less dense sea ice cover (profile $x$ in Fig. 7). A warming of the WW due to summer surface waters, however, should be accompanied by a freshening of the water mass. Since the latter was not observed and water mass characteristics on the northwestern Weddell Sea continental shelf were similar to those in the central basin of the Bransfield Strait, we favor a southward advance of waters of Bransfield Strait origin in summer and their retreat during the winter months. The shallow moorings (AWI_234 and AWI_215) of von Gyldenfeldt et al. (2002) do not unconditionally support a southward advection in summer but show events of southerly flow from October to February (their Figure 5).

\subsection{Winter conditions}

Winter-2006 conditions on the northwestern Weddell Sea continental shelf (Fig. 3) are characterized by the existence of a MWDW core at its rim, mixing with shelf water at the surface freezing point. The comparison at two sites (I and II in Fig. 1b) with nearby stations, occupied in the austral winters of 1989 and 1997, shows a gradual freshening of the densest water of 0.09 for the 17 -yr period (Fig. 3). The freshening is evident from top to bottom of the $<200$-m deep water column (Fig. 8). The excursions of the earlier profiles in the top $100 \mathrm{~m}$ towards lower salinity, as observed for region II, are probably due to the melt of icebergs, preferably grounded at the continental shelf break (C. Wesche, personal communication, 2010). The salinity decrease is stronger during the 1989-1997 period (discussed below), but the total of 0.09 is comparable to the salinity decrease of 0.2 over $+40 \mathrm{yr}$ on the southern Ross Sea continental shelf (Jacobs and Giulivi, 2010). Here, an increased freshwater flux due to enhanced melting of ice shelves fringing the Amundsen Sea was suggested to be the cause. The thinning of Larsen Ice Shelf was attributed to increased basal melting due to warmer shelf waters (Shepherd et al., 2003), although a warming on the western Weddell Sea continental shelf lacks observations (e.g., Nicholls et al., 2004). Nevertheless, the presence of ISW with temperatures below surface freezing at the northern front of Larsen C Ice Shelf (Fig. 6) as well as on the western Weddell Sea continental shelf (Weppernig et al., 1996; Huhn et al., 2008), and the high Ne values at the southernmost stations in winter 2006 (Fig. 4) all indicate the input of fresh water due to ice shelf basal melting.

In the following, we estimate the amount of glacial melt water on the western Weddell Sea continental shelf for the winter of 2006. According to the bathymetry compiled by Timmermann et al. (2010), the continental shelf volume $(<500 \mathrm{~m})$ from the northern edge of Larsen $\mathrm{C}\left(66^{\circ} \mathrm{S}\right)$ to the southern rim of the central basin of Bransfield Strait $\left(\sim 62^{\circ} \mathrm{S}\right)$ amounts to $4 \times 10^{4} \mathrm{~km}^{3}$. With a mean GMW fraction of $0.25 \%$ (Fig. 5) the total GMW volume results to $100 \mathrm{~km}^{3}$. The decay of Larsen A in 1995 and Larsen B in 2002/03 reduced the total area of ice shelf base to finally $73000 \mathrm{~km}^{2}$ (Shepherd et al., 2010). Therefore, in order to account for the GMW volume in 2006 the base of Larsen C had to melt at a rate of $1.5 \mathrm{~m} \mathrm{a}^{-1}$ (ice density $917 \mathrm{~kg} \mathrm{~m}^{-3}$ ), assuming that no GMW (e.g. from Ronne Ice Shelf) was advected into the region from the south. In-situ observations of melting underneath Larsen Ice Shelf do not exist. However, satellite observations indicate a volume loss of $62 \pm 4 \mathrm{~km}^{3}$ per year for the period 1994-2008 (Shepherd et al., 2010) which, if solely due to basal melting, would be equivalent to a rate of $0.85 \pm 0.05 \mathrm{~m} \mathrm{a}^{-1}$. An even smaller melt rate of $0.35 \pm 0.19 \mathrm{~m} \mathrm{a}^{-1}$ was deduced from tracer analysis, based on the continental shelf and slope stations occupied during AS_04 (Huhn et al., 2008). A mean melting of $1.26 \mathrm{~m} \mathrm{a}^{-1}$ resulted from the application of a two-dimensional plume model to the Larsen C cavity for a "warm case", prescribing an ambient water temperature of $-1.4^{\circ} \mathrm{C}$ (Holland et al., 2009). At the westernmost station (AS_92-73) of the shelf section perpendicular to the southern front of Larsen C Ice Shelf (Fig. 1a) near-bottom tempeartures were colder than $-1.7^{\circ} \mathrm{C}$, but a maximum of $-1.5^{\circ} \mathrm{C}$ existed at $150 \mathrm{~m}$ depth.

The clear separation in summer between warm shelf waters to the north and cold waters to the south (Fig. 6) and the dominance of southern characteristics on the whole northwestern continental shelf in winter indicate a northward transport of southern water masses some time in fall. The 

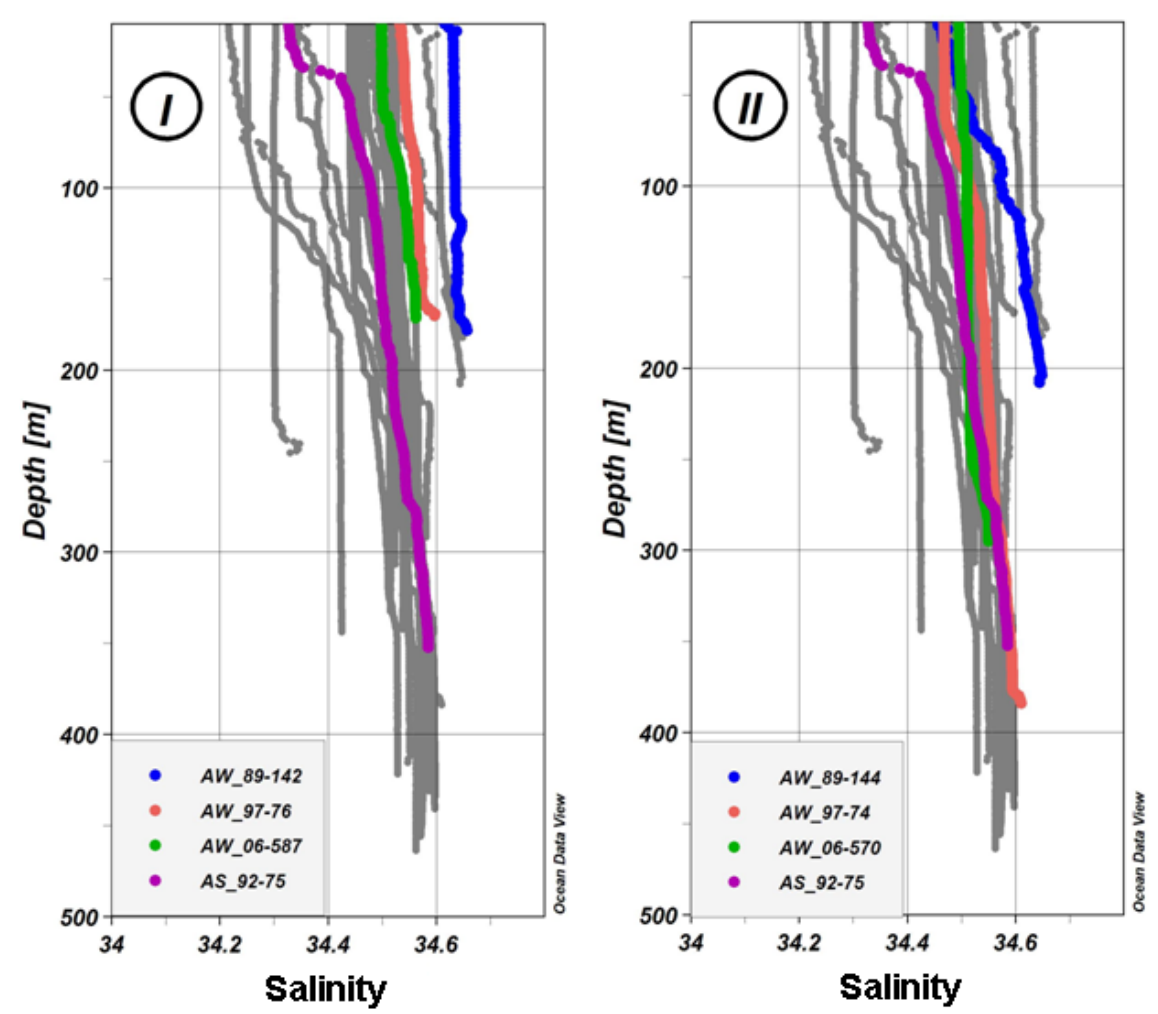

Fig. 8. Austral winter salinity profiles from the shallow $(<500 \mathrm{~m})$ northwestern Weddell Sea continental shelf for cruises AW_89, AW_97, and AW_06, in gray, together with selected stations from the areas I and II (Fig. 1b), sampled during 1989 (blue), 1997 (red), and 2006 (green). In addition, a characteristic profile from the continental shelf south of Larsen C Ice Shelf (purple) measured during cruise AS_92. See Fig. 1a for station location.

deep Weddell Sea is dominated by a cyclonic gyre circulation, but a broader continental shelf with banks and troughs, like in the southern Weddell Sea, tends to support its own circulation pattern (e.g., Grosfeld et al., 2001). Though patchy, bottom topography in the western Weddell Sea indicates the existence of banks (Luckman et al., 2009), basins, and troughs (Timmermann et al., 2010) which would allow currents without a predominant south/north orientation. Currents still need to be recorded on the western continental shelf, but observations above the slope (Muench and Gordon, 1995), remotely controlled sea ice advection (Kottmeier and Sellmann, 1996) and iceberg drift (Schodlok et al., 2006), as well as numerical model results (Hellmer et al., 2009) all indicate a northward advection of shelf waters. Assuming the western most iceberg drift of $3 \mathrm{~km}$ per day to be representative for advection on the western continental shelf, glacial melt water would be transported within $\sim 110$ days from the northern Larsen $\mathrm{C}$ front $\left(66^{\circ} \mathrm{S}\right)$ to the tip of the Antarctic Peninsula $\left(63^{\circ} \mathrm{S}\right)$. With the same velocity the "thermal front" would be displaced within $\sim 30$ days from its southern position beyond the northernmost hydrographic winter stations. This indicates that the shelf water in the western Weddell Sea, not being trapped in deep basins (Gilbert et al., 2003), has a residence time of less than one year.
To clarify whether the salinity decrease observed in winter at the tip of the Antarctic Peninsula is solely related to an increased freshwater input on the western Weddell Sea continental shelf, the shelf water characteristics at its inflow, i.e. south of Larsen C, have to be looked at. Observations on in the western Weddell Sea are sparse. The only CTDsection extending from the southern front of Larsen $\mathrm{C}$ to the continental shelf break was done in austral summer 1992/93 (AS_92), roughly mid-time between the first two winter observations to the north. Although from a different season, the consideration of the southern profiles is allowed, since model results from the continental shelf south of Larsen C (Haid et al., 2010) indicate that the water column below the summer surface layer does not experience any seasonal changes. The comparison of the observed salinity profiles shows that, at least for the years after 1993, the upper $200 \mathrm{~m}$ of the water column gained salt as it moved to lower latitudes on the western Weddell Sea continental shelf (Fig. 8). Therefore, based on the latter the observed winter freshening can also be interpreted as a decrease in salt input related to reduced sea ice formation.

The comparison of two SSMI/I (Cavalieri et al., 2006) derived decadal mean summer (March) sea ice concentrations (1979-1988 and 1997-2006) shows that the sea ice edge 

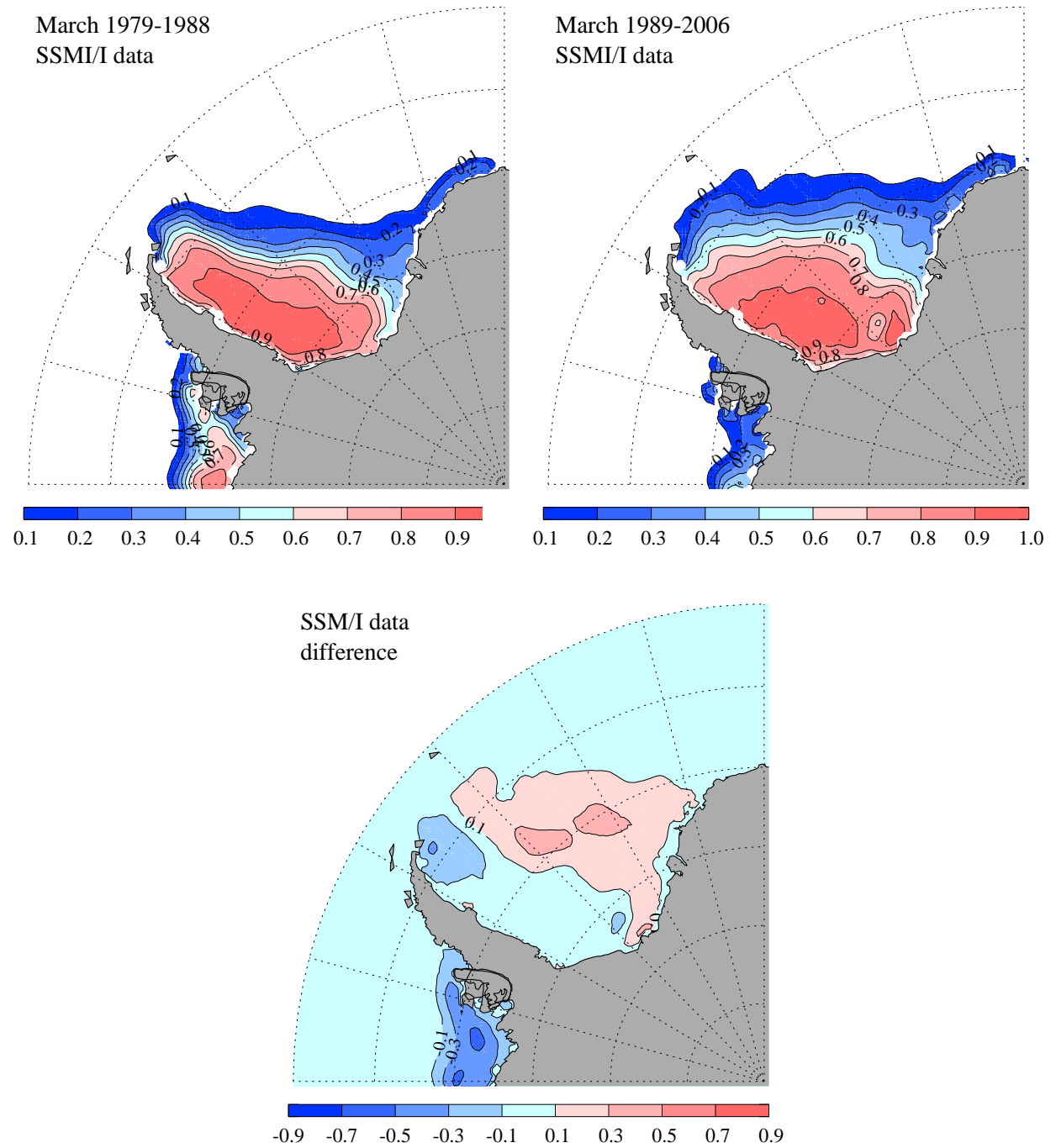

Fig. 9. SSMI/I derived decadal mean summer (March) sea ice concentration [\%] for the periods 1979-1988 (upper left) and 1989-2006 (upper right) for the sector $0^{\circ}-90^{\circ} \mathrm{W}$ of the Southern Ocean. The diffence between both periods (lower panel) shows sea ice concentration being most reduced (up to $50 \%$ ) on the continental shelf off the tip of the Antarctic Peninsula.

moved southward on the northwestern Weddell Sea continental shelf during the 30-yr period (Fig. 9). It might be just a coincidence that for the second decade the isoline of $>20 \%$ concentration is located at $64^{\circ} \mathrm{S}$, the position of the thermal front in the austral summers of 2006/07 and 2008/09. A more southerly sea ice edge indicates more melting of sea ice and thus an enhanced freshwater input to the continental shelf. In addition, a sea ice-free area allows for a warming of the surface layer in summer and for precipitation to directly freshen the water column instead of being advected with the sea ice till the ice floe decays. A warmer surface layer delays sea ice formation in the following winter. A fresher surface layer supports a thicker sea ice cover (Hellmer, 2004), because it stabilizes the water column and thus hampers the mixing of warmer waters (MWDW) into the surface layer, where it would melt the sea ice. However, if sea ice forma- tion (and brine rejection) on the continental shelf has to get over a stronger seasonal pyconcline in less time, the salt input to the bottom layer is reduced.

The results of atmospheric analyses and re-analyses products together with a dynamic retrieval method to calculate precipitation for the period 1979 to 1999 show higher amplitudes and a higher annual mean precipitation for the South Atlantic sector $\left(65^{\circ}-75^{\circ} \mathrm{S}, 30^{\circ}-60^{\circ} \mathrm{W}\right)$ starting in 1988 (Fig. 16 in Bromwich et al., 2004). Considering the two peaks in 1989 and 1996, representing an increase in precipitation of $0.16 \mathrm{~m} \mathrm{a}^{-1}$ and $0.12 \mathrm{~m} \mathrm{a}^{-1}$, respectively, the volume of freshwater added within one year to the surface area of $1.652 \times 10^{5} \mathrm{~km}^{2}$, used above to calculate the water volume on the northwestern continental shelf $(<500 \mathrm{~m})$, would rise to $26 \times 10^{9} \mathrm{~m}^{3}\left(26 \mathrm{~km}^{3}\right)$ and $20 \times 10^{9} \mathrm{~m}^{3}\left(20 \mathrm{~km}^{3}\right)$. This would lower the salinity of the volume by 0.02 and 0.017 , 


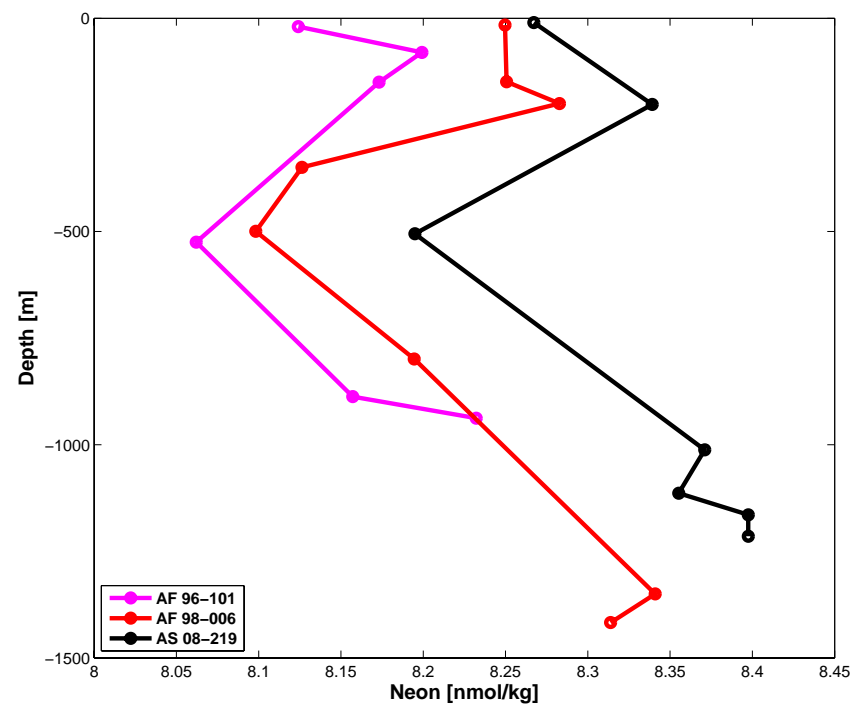

Fig. 10. $\mathrm{Ne}\left[\mathrm{nmol} \mathrm{kg}^{-1}\right]$ profiles from repeat stations in close proximity on the continental slope (1000-1400 m depth, magenta circle in Fig. 2) in the northwestern Weddell Sea slightly northeast of the AW_06 stations in austral summers of 1996 (purple), 1998 (red), and 2008 (black). Ne concentrations increase systematically over the whole water column by roughly $0.1 \mathrm{nmol} \mathrm{kg}^{-1}$ per decade.

respectively. Such fluctuations are similar to the salinity changes recorded on the continental slope to the east of the Antarctic Peninsula's tip at a depth of $\sim 2500 \mathrm{~m}$ (Fig. 11 in Schröder et al., 2002). Events of high precipitation are also confirmed by the accumulation rates deduced from an ice core drilled on James Ross Island (Miles et al., 2008); accumulation peaked in 1989, 1992, 1997, and 2000, although with a decreasing trend. The latter is confirmed by the results of the regional atmosphere model (RACMO2), showing a decrease in annual mean precipitation reaching the ocean of $\sim 20 \mathrm{~km}^{3}$ for the period 1989-2006 (Lenaerts et al., 2011). This reduction in freshwater input is not compensated by the increase in continental run-off of $5 \mathrm{~km}^{3}$ for the same period and sector (Lenaerts et al., 2011). In addition, the freshwater increase due to continental run-off is neglegible compared to the fluctuations in precipitation reaching the ocean, which can be as large as $100 \mathrm{~km}^{3}$.

\section{Conclusions}

We assume that the freshening of 0.09 observed on the northwestern Weddell Sea continental shelf for the austral winters from 1989 to 2006 was caused by a decrease of salt input due to a southward sea ice retreat and higher precipitation during the late 20th century. The maximum fluctuation in precipitation of $100 \mathrm{~km}^{3}$ is sufficient to reduce the salinity on the continental shelf by 0.085 , but we can only relate the 1997 freshening of the water column with a precipitation peak in the previous year. The reduced salt input, however, might have happened in concert with an increase in ice shelf mass loss, counteracting an enhanced salt input due to sea ice formation in coastal areas formerly occupied by Larsen A and B ice shelves (C. Haas, personal communication, 2010). Indeed, a time series of noble gas observations on a repeat section covering the continental shelf and slope in the northwestern Weddell Sea (slightly north of the AW_06 stations) shows austral summer Ne concentrations to increase systematically over the whole water column by roughly $0.10 \mathrm{nmol} \mathrm{kg}^{-1}$ per decade (Fig. 10).

The freshening and spring-cooling observed on the continental slope ( $\sim 2450$-m depth) off the tip of the Antarctic Peninsula (von Gyldenfeldt et al., 2002) might be related to the southward progression of warmer waters of Bransfield Strait origin, diverting the shelf waters with southern characteristics towards greater depth. A meridional fluctuation of the position of the thermal front could therefore allow for Bransfield Strait waters to reach the base of the ice shelves fringing the western Weddell Sea. The lack of information on the freshwater/salt balance calls for further investigation of the northwestern Weddell Sea continental shelf for all seasons covering hydrographic and glaciological surveys, satellite observations, and numerical model studies. Our work also suggests to act with caution when relating a shelf water freshening solely to an increased contribution of glacial melt water.

Acknowledgements. We thank captain and crew of R/V Polarstern cruise ANT-XXIII/7 and the members of the Logistic Department at Alfred Wegener Institute for Polar and Marine Research (AWI) for their support. Special thanks to M. Schodlok, M. Mata, N. Nunes, R. Kerr, M. Rücker van Caspel, A. Macrander, and L. Sellmann, members of the oceanographic team during ANT-XXIII/7, and to A. Wisotzki for advice during data processing. D. Gomis acknowledges the funding of the projects ATOS (POL2006-00550/CTM) and ESASSI (POL2006-11139-C02-01/CGL) by the Spanish Polar Research Sub-Program and the FEDER program of the European Union. We also thank E. Isla for collecting and providing the CTD data of cruise ANT-XXIII/8. The provision of the NBP9705 hydrographic data by B. Huber (LDEO) and modeled precipitation and continental run-off by J. T. M. Lenaerts (IMAU) was very much appreciated. The paper improved significantly due to the discussion with M. Schröder and constructive comments by C. Haas and one anonymous reviewer.

Edited by: G. Williams

\section{References}

Absy, J. M., Schröder, M., Muench, R., and Hellmer, H. H.: Early summer thermohaline characteristics and mixing in the western Weddell Sea, Deep-Sea Res. Pt. II, 55(8-9), 1117-1131, 2008.

Augstein, E., Bagriantsev, N. V., and Schenke, H.-W.: The expedition ANTARKTIS VIII/1-2, 1989 with the Winter Weddel Gyre study of the research vessels "Polarstern" and "Akademik Fedorov", Reports on Polar Research, 84, 134 pp., 1991. 
Braun, M. and Humbert, A.: Recent retreat of Wilkins Ice Shelf reveals new insights in ice shelf break-up mechanisms, IEEE Geosci. Remote S., 6(2), 263-267, doi:10.1109/LGRS.2008.2011925, 2009.

Bromwich, D. H., Guo, Z., Bai, L., and Chen, Q.-S.: Modeled Antarctic precipitation. Part I: spatial and temporal variability, J. Climate, 17, 427-447, 2004.

Bulsiewicz, K., Rose, H., Klatt, O., Putzka, A., and Roether, W.: A capillary-column chromatographic system for efficient chlorofluoromethane measurement in ocean waters, J. Geophys. Res., 103, 15959-15970, 1998.

Cavalieri, D., Parkinson, C., Gloersen, P., and Zwally, H. J.: Sea ice concentrations from Nimbus-7 SMMR and DMSP SSM/I passive microwave data, January 1979-June 2006, Boulder, Colorado USA: National Snow and Ice Data Center, digital media, 1996, updated 2006.

Garcia, C. A. E. and Mata, M. M.: Deep and bottom water variability in the central basin of Bransfield Strait (Antarctica) over the 1980-2005 period, CLIVAR Exchanges, 10(4), 48-50, 2005.

Gilbert, R., Domack, E. W., and Camerlenghi, A.: Deglacial history of the Greenpeace Trough: ice sheet to ice shelf transition in the northwestern Weddell Sea, in: Antarctic Peninsula climate variability, edited by: Domack, E. W., Leventer, A., Burnett, A., Bindschadler, R., Convey, P., and Kirby, M., Antarctic Research Series, 79, AGU, Washington DC, 195-204, 2003.

Gill, A. E.: Circulation and bottom water production in the Weddell Sea, Deep-Sea Res. Pt. I, 20, 111-140, 1973.

Gordon, A. L.: Western Weddell Sea thermohaline stratification, in: Ocean, Ice, and Atmosphere, edited by: Jacobs, S. S. and Weiss, R. F., Antarctic Research Series, 75, AGU, Washington DC, 215-240, 1998.

Gordon, A. L., Mensch, M., Dong, Z., Smethie Jr., W. M., and de Bettencourt, J.: Deep and bottom water of the Bransfield Strait eastern and central basins, J. Geophys. Res., 105, 11337-11346, 2000.

Grosfeld, K., Schröder, M., Fahrbach, E., Gerdes, R., and Mackensen, A.: How iceberg calving and grounding change the circulation and hydrography in the Filchner Ice Shelf-Ocean System, J. Geophys. Res., 106(C5), 9039-9055, doi:2000JC000601, 2001.

Gutt, J.: The expedition ANTARKTIS-XXIII/8 of the research vessel "Polarstern" in 2006/2007: ANT-XXIII/8; 23 November 2006-30 January 2007 Cape Town-Punta Arenas, Reports on Polar and Marine Research, 569, 153 pp., hdl:10013/epic.28679.d001, 2008.

Haid, V., Timmermann, R., Heinemann, G., and Ebner, L.: Simulation of coastal polynyas and related ocean processes in the western Weddell Sea, Terra Nostra-2010/5, 24, Internationale Polartagung, Obergurgl, Austria, 2010.

Hellmer, H. H.: Impact of Antarctic ice shelf melting on sea ice and deep ocean properties, Geophys. Res. Lett., 31, L10307, doi:10.1029/2004GL019506, 2004.

Hellmer, H. H., Schröder, M., Haas, C., Dieckmann, G. S., and Spindler, M.: The ISPOL drift experiment, Deep-Sea Res. Pt. II, 55(8-9), 913-917, 2008.

Hellmer, H. H., Kauker, F., and Timmermann, R.: Weddell Sea anomalies: Excitation, propagation, and possible consequencs, Geophys. Res. Lett., 36, L12605, doi:10.1029/2009GL038407, 2009.
Hohmann, R., Schlosser, P., Jacobs, S. S., Ludin, A., and Weppernig, R.: Excess helium and neon in the southeast Pacific. Tracers for glacial melt water, J. Geophys. Res., 107(C11), 3198, doi:10.1029/2000JC000378, 2002.

Holland, P. R., Corr, H. F. J., Vaughan, D. G., Jenkins, A., and Skvarca, P.: Marine ice in Larsen Ice Shelf, Geophys. Res. Lett., 36, L11604, doi:10.1029/2009GL038162, 2009.

Huhn, O., Hellmer, H. H., Rhein, M., Rodehacke, C. B., Roether, W., Schodlok, M. P., and Schröder, M.: Evidence of deep and bottom water formation in the western Weddell Sea, Deep-Sea Res. Pt. II, 55(8-9), 1098-1116, 2008.

Jacobs, S. S. and Giulivi, C. F.: Large multidecadal salinity trends near the Pacific-Antarctic continental margin, J. Climate, 23, 4508-4524, 2010.

King, J. C.: Recent climate variability in the vicinity of the Antarctic Peninsula, Int. J. Climatol., 14, 357-369, 1994.

Kottmeier, C. and Sellmann, L.: Atmospheric and oceanic forcing of Weddell Sea ice motion, J. Geophys. Res., 101(C9), 2080920824, 1996.

Lemke, P.: The expedition of the research vessel "Polarstern" to the Antarctic in 2006 (ANT-XXIII/7), Reports on Polar and Marine Research, 586, 147 pp., hdl:10013/epic.31915.d001, 2009.

Lenaerts, J. T. M., van den Broeke, M. R., van de Berg, W. J., van Meijgaard, E., and Kuipers Munneke, P.: A new, high-resolution surface mass balance map of Antarctica, Geophys. Res. Lett., accepted, 2011.

Luckman, A., Padman, L., and Jansen, D.: Persistent iceberg groundings in the western Weddell Sea, Remote Sens. Environ., 114(2), 385-391, doi:10.1016/j.rse.2009.09.009, 2009.

Meredith, M. P. and King, J. C.: Rapid climate change in the ocean west of the Antarctic Peninsula during the second half of the 20th century, Geophys. Res. Lett., 32, L19604, doi:10.1029/2005GL024042, 2005.

Miles, G. M., Marshall, G. J., McConnell, J. R., and Aristarain, A. J.: Recent accumulation variability and change on the Antarctic Peninsula from the ERA-40 reanalysis, Int. J. Climatol., 28, 1409-1422, doi:10.1002/joc.1642, 2008.

Muench, R. D. and Gordon, A. L.: Circulation and transport of water along the western Weddell Sea margin, J. Geophys. Res., 100(C9), 18503-18515, 1995.

Muench, R. D. and Hellmer, H. H.: The international DOVETAIL program, Deep-Sea Res. Pt. II, 49(21), 4711-4714, 2002.

NOAA: CDC Derived NCEP Reanalysis Products Surface Level GrADS image, http://www.esrl.noaa.gov/psd, 2009.

Nicholls, K. W., Pudsey, C. J., and Morris, P.: Summertime water masses off the northern Larsen C ice Shelf, Antarctica, Geophys. Res. Lett., 31, L09309, doi:10.1029/2004GL019924, 2004.

Prinn, R. G., Weiss, R. F., Fraser, P. J., Simmonds, P. G., Cunnold, D. M., Alyea, F. N., O’Doherty, S., Salameh, P., Miller, B. R., Huang, J., Wang, R. H. J., Hartley, D. E., Harth, C., Steele, L. P., Sturrock, G., Midgley, P. M., and McCulloch, A.: A history of chemically and radiatively important gases in air deduced from ALE/GAGE/AGAGE, J. Geophys. Res., 105, 17751-17792, 2000.

Rack, W. and Rott, H.: Pattern of retreat and disintegration of Larsen B ice shelf, Antarctic Peninsula, Ann. Glaciol., 39, 505510, 2004.

Rignot, E. and Jacobs, S. S.: Rapid bottom melting widespread near Antarctic ice sheet grounding lines, Science, 296, 2020-2023, 
2002.

Rintoul, S. R.: Rapid freshening of Antarctic Bottom Water formed in the Indian and Pacific oceans, Geophys. Res. Lett., 34, L06606, doi:10.1029/2006GL028550, 2007.

Robertson, R., Padman, L., and Egbert, G. D.: Tides in the Weddell Sea, in: Ocean, Ice, and Atmosphere, edited by: Jacobs, S. S. and Weiss, R. F., Antarctic Research Series, 75, AGU, Washington DC, 341-369, 1998.

Schodlok, M. P., Hellmer, H. H., Rohardt, G., and Fahrbach, E.: Weddell sea-iceberg drift: 5 years of observations, J. Geophys. Res., 111, C06018, doi:10.1029/2004JC002661, 2006.

Schröder, M., Hellmer, H. H., and Absy, J. M.: On the near-bottom variability in the northwestern Weddell Sea, Deep-Sea Res. Pt. II, 49(21), 4767-4790, 2002.

Shepherd, A., Wingham, D. J., Payne, T., and Skvarca, P.: Larsen Ice Shelf has progressively thinned, Science, 302, 856-859, 2003.

Shepherd, A., Wingham, D., Wallis, D., Giles, K., Laxon, S., and Sundal, A. V.: Recent loss of floating ice and the consequent sea level contribution, Geophys. Res. Lett., 37, L13503, doi:10.1029/2010GL042496, 2010.

Sültenfuß, J., Roether, W., and Rhein, M.: The Bremen Mass Spectrometric Facility for the measurement of helium isotopes, neon, and tritium in water, Isot. Environ. Healt. S., 45(2), 1-13, 2009.
Timmermann, R., Le Brocq, A., Deen, T., Domack, E., Dutrieux, P., Galton-Fenzi, B., Hellmer, H., Humbert, A., Jansen, D., Jenkins, A., Lambrecht, A., Makinson, K., Niederjasper, F., Nitsche, F., Nst, O. A., Smedsrud, L. H., and Smith, W. H. F.: A consistent dataset of Antarctic ice sheet topography, cavity geometry, and global bathymetry, Earth Syst. Sci. Data Discuss., 3, 231-257, doi:10.5194/essdd-3-231-2010, 2010.

Tomczak, M.: A multi-parameter extension of temperature/salinity diagram techniques for the analysis of non-isopycnal mixing, Prog. Oceanogr., 10, 147-171, 1981.

Tomczak, M. and Large, D. G. B.: Optimum Multiparameter Analysis of Mixing in the thermocline of the Eastern Indian Ocean, J. Geophys. Res., 94(C11), 16141-16149, 1989.

von Gyldenfeldt, A.-B., Fahrbach, E., Garcia, M. A., and Schröder, M.: Flow variability at the tip of the Antarctic Peninsula, DeepSea Res. Pt. II, 49(21), 4743-4766, 2002.

Weppernig, R., Schlosser, P., Khatiwala, S., and Fairbanks, R. G.: Isotope data from Ice Station Weddell: Implications for deep water formation in the Weddell Sea, J. Geophys. Res., 101(C11), 25723-25739, 1996. 